\title{
Danske seniorers (65+) motiver og barrierer for fysisk aktivitet
}

\section{Danish older adults $(65+)$ motives and barriers for physical activity}

\author{
Merete Lundby Larsen ${ }^{\mathbf{1}}$ \& Knud Ryom ${ }^{1}$ \\ ${ }^{1}$ Department of Public Health, Aarhus University, Aarhus, Denmark
}

Corresponding author: Merete Larsen

E-mail: meretellarsen@hotmail.com

Department of Public Health

Aarhus University

Bartholins allé 2, 8000 Aarhus C. Denmark

Abstract

The proportion of older adults is increasing in Denmark. At the same time physical activity is becoming an increasingly popular arena to prevent illness, promote health and increase life quality. This case study examined older adults' (65-75 y) motives and barriers for participation in organised physical activity. Using a single embedded case study, we collected data through semi structured interviews and observation. The theoretical framework is Ryan \& Deci's Self-Determination Theory (SDT). Results of this study indicate that informants had several intrinsic and extrinsic motives. Among the extrinsic motives were better health, absence of illness, a good retirement and complying with social norms. A number of integrated and structural motives also exist: positive experience with sports, appropriate challenges, social interaction, diverse sports activities and freedom of choice. The older adults described barriers such as: difficult to self-initiate participation in sports, health related issues and lacking experiences with sports. Furthermore, the study discusses behaviour change triggers to stimulate healthy behaviour in old age using a revised FBM-model. In addition, organised physical activity that promotes satisfaction of the psychological needs is essential for the adherence. Based on the results and discussion, implications for practice are provided through recommendations on physical activity for older adults, based on organisation, activities and recruitment.

Keywords: motivation, health behavior, older adult physical activity, physical activity.

Fysisk aktivitet blandt seniorer er et vigtigt område at beskæftige sig med i relation til folkesundhed. Andelen af den danske befolkning som er over 65 år stiger mærkbart (Sundhedsstyrelsen, 2019b). I 2020 nåede andelen af seniorer over 65 år op på $20 \%$ af den danske befolkning svarende til, at hver femte dansker er over 65 àr (Ældresagen, 2020). Hvor andelen i 1990 udgjorde $16 \%$, forventes den i 2050 at udgøre $24 \%$ (Sundhedsstyrelsen, $2019 b)$, mens antallet af seniorer over 80 år forventes at fordobles (Vive, 2020). I takt med denne udvikling er det ifølge Sundhedsstyrelsen (2019b) vigtigt at have fokus på seniorernes livskvalitet, helbred og trivsel i de ekstra leveår, hvorfor sundhedsfremme i denne befolkningsgruppe er centralt. Fysisk aktivitet er et centralt område for seniorer, da det netop kan påvirke livskvalitet, helbred og trivsel (Bangsbo et al., 2019).

Fysisk aktivitet anerkendes i stigende grad for at have potentiale til at forebygge sygdom, forbedre sundhed, øge livskvalitet og danne stærke relationer i alle aldersgrupper, herunder seniorer (Kulturministeriet, 2009). Dette er for nyligt blevet understreget i Copenhagen
Consensus statement 2019 om aldring, med deltagelse af en lang række anerkendte forskere indenfor fysisk aktivitet (Bangsbo et al., 2019), samt det anerkendes bredt af staten og det danske sundhedsvæsen (Sundhedsstyrelsen, 2018c).

Seniorer (i dette studie forstået som 65-75 årige), som er fysisk aktive, har signifikant lavere risiko for en lang række sygdomme, herunder diabetes, hjertesygdom, depression, osteoporose, kardiovaskulære sygdomme og flere forskellige cancerformer. Der er evidens for at seniorer som er fysisk aktive, lever længere end fysisk inaktive seniorer (Sundhedsstyrelsen, 2018c). Forskning viser endvidere, at fysisk aktivitet ikke blot lægger àr til livet, men også liv til årene, idet fysisk aktivitet kan styrke seniorers fysiske funktionsevne og kognitive funktion, have positiv effekt på søvn, selvfølelse, livskvalitet og den generelle selvoplevede sundhed (Sundhedsstyrelsen, 2018c). Undersøgelser af de sundhedsøkonomiske udgifter forbundet med fysisk inaktive seniorer viser, at en stigning i seniorers fysiske aktivitetsniveau kan medføre besparelser på behandling og pleje af fysisk inaktive 
seniorer og dermed spare samfundet for millioner af kroner på social- og sundhedsudgifter årligt (Eriksen et al., 2016). Fysisk aktivitet kan således imødekomme mange af de udfordringer, som den voksende seniorpopulation kan medføre, både i henhold til menneskelig trivsel og samfundsøkonomiske problematikker (Sundhedsstyrelsen, 2019b).

De seneste 20 år er det blevet markant mere udbredt for seniorer at motionere og dyrke sport (Vive, 2020). Cirka $60 \%$ af de $60+$ årige danskere dyrker normalt organiseret idræt eller motion (Rask \& Eske, 2020). Der er dog registreret et fald på $5 \%$ i de seneste 4 år, hvilket i høj grad kan tilskrives Covid-19 (Pilgaard \& Rask, 2016b; Rask \& Eske, 2020). Således er op til $40 \%$ af seniorerne fortsat fysisk inaktive og blandt de 65-74-årige er der 27 $\%$ af mændene og $26 \%$ af kvinderne som ikke overholder WHO's anbefalinger for fysisk aktivitet og blandt seniorerne over 75 år er andelen henholdsvis 39 og $46 \%$ (Sundhedsstyrelsen, 2018). Samtidig ved vi, at omkring $50 \%$ af de fysisk inaktive seniorer har et ønske om at være mere fysisk aktive (Sundhedsstyrelsen, 2018), og der er altså et stort potentiale for at endnu flere seniorer kan blive fysisk aktive.

Dette studie er et casestudie, der teoretisk tager afsæt i Deci \& Ryans Self-Determination Theory (SDT). Formålet med studiet er at kvalificere og nuancere viden om, hvorfor seniorer vælger at initiere fysisk aktivitet, hvad man kan gøre for, at de bliver ved med at være fysisk aktive og hvad der får seniorer til at fravælge fysisk aktivitet. Med studiet ønskes følgende forskningsspørgsmål besvaret: Hvilke motiver og barrierer oplever 65-75 årige seniorer for at gå til Idræt om dagen ${ }^{1}$ (IOD)?

\section{Baggrundsafsnit}

Kun få studier undersøger seniorers motiver og barrierer i relation til foreningsidrætten (DIF, 2020; Kulturministeriet, 2009; Toft, 2013), mens flere rapporter har fokus på fysisk aktivitet og inaktivitet generelt (L. O. Ottesen, Skjerk, \& Vang, 2006; Pilgaard \& Rask, 2016a). Desuden findes rapporter, hvor der er fokus på den voksne $(16+)$ befolkning som helhed (Pilgaard \& Rask, 2016a; Ryom et al., 2020; Sundhedsstyrelsen, 2003), og ikke på seniorgruppen specifikt. Der er en del sammenfald $i$ resultaterne fra overstående, såsom at seniorers motiver for fysisk aktivitet er: bedre form, helbred, socialt samvær, fleksibilitet, idræt med personer med samme niveau, mere fritid, frygt for overvægt og sygdom. De oftest fremførte barrierer er: skader, dårligt helbred, prioritet af andre interesser, mangle en at følges med, ikke rigtigt idrætstilbud, for dyrt, manglende tid og overskud samt frygt for niveauforskel.

De eksisterende undersøgelser adskiller sig fra dette studie med hensyn til dataindsamlingsmetoder og afgrænsning af den fysiske aktivitet. Hvor de tidligere studier tager et bredt sigte på fysisk aktivitet, anlægges i denne undersøgelse udelukkende fokus på den organiserede foreningsidræt. Dertil kommer, at de eksisterende undersøgelser overvejende er større kvantitative undersøgelser, hvor der er anvendt spørgeskemaundersøgelser som dataindsamlingsmetode og problemstillingen er undersøgt ud fra en række på forhånd opstillede mulige motiver og barrierer. Grunden til at dette divergerende valg er ønsket om at få nuancerede og deltaljerede beskrivelser af seniorernes motiver og barrierer gennem kvalitative

1 Idræt om dagen er et senioridrætstilbud til DGI's medlemsforeninger. Seniorerne mødes på en fast ugedag i 2 timer om formiddagen til fælles opvarmning og forskellige idrætsaktiviteter. Det er forskelligt, hvilke aktiviteter foreningerne udbyder. Seniorerne vælger selv hvilke aktiviteter, de vil deltage interviews, der tillader en åbenhed over for forskelligheder og skævheder.

\section{Teoretisk baggrund}

\section{Self-Determination Theory}

Self-Determination Theory (SDT) af Deci \& Ryan benyttes som studiets teoretiske ramme. Teorien er en af de mest underbyggede og anerkendte inden for motivationsteori (Sheldon, 2012). SDT spænder fra amotivation til intrinsisk motivation og graden af selvbestemmelse er den mest afgørende faktor for hvor på kontinuummet, motivationsformen er placeret, hvor en høj grad af selvbestemmelse determinerer intrinsisk motivation (Ryan \& Deci, 2000b).

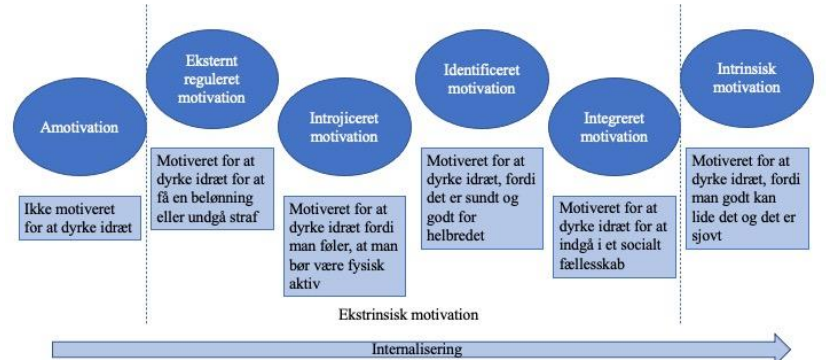

Figur 1. SDT motivationsformer inspireret af Ryan and Deci (2000) med idrætsspecifikke eksempler

En grundantagelse i SDT er, at mennesket har tre psykologiske, medfødte, universelle behov: autonomi, kompetence og tilhørsforhold (Ryan \& Deci, 2000). Autonomi refererer til en indre tilstand, hvor man oplever, at den adfærd, man udøver er viljesbestemt og selvendosseret frem for at være kontrolleret eller tvunget af udefra stående faktorer (Ryan \& Deci, 2000). Behovet for kompetence opfyldes, når ens færdigheder, viden og erfaringer er tilstrækkelige i en given situation (Deci \& Ryan, 1985). Behovet for tilhørsforhold refererer til, at man har behov for at føle sig forbundet til andre, at føle sig inkluderet og værdsat af andre inden for det domæne, man handler i (Ryan, Williams, Patrick, \& Deci, 2009). Hvis behovene tilfredsstilles, fremmer det intrinsisk motivation, sundhed og trivsel, og hvis ikke, bidrager det til sygdom, utilpashed og amotivation (Ryan \& Deci, 2000).

Intrinsisk motivation er karakteriseret ved, at adfærden sker spontant og at aktiviteten i sig selv er forbundet med glæde og fornøjelse. Selvom der kan være sekundære gevinster ved aktiviteten, er den primære belønning iboende i selve aktiviteten (Deci \& Ryan, 1985). Den indre motivation manifesterer sig i fx forbedret præstation og vedholdenhed i det, man laver og øget trivsel og sundhed (Ryan \& Deci, 2000). Ekstrinsisk motivation er năr man udfører en handling for at opnå et separat og ofte resultatorienteret udfald (Ryan \& Deci, 2000). Meget af det, mennesket gør, er ikke intrinsisk motiveret. Vi udfører aktiviteter, der ikke er interessante som eksempelvis pligter, der skal udføres (Ryan \& Deci, 2000). Ekstrinsisk motivation er en kompleks kategori af motivation, der består af en differentieret taksonomi med flere typer

. Den sociale dimension er vigtig og aktiviteterne afsluttes typisk med fælles kaffe, sang og snak. 
ekstrinsisk motivation, der varierer i relativ autonomi (Ryan et al., 2009). Foruden intrinsisk og ekstrinsisk motivation, indgăr der i SDT også amotivation. Når man er amotiveret, mangler man en intention til at handle (Ryan \& Deci, 2000). Det kommer til udtryk ved, at man enten slet ikke gør noget eller blot udfører reflekslignende bevægelser.

\section{Fogg's Behavioral Model}

SDT kan fortælle noget om motivation som helhed (Sheldon, 2012), men ikke hvad der konstituerer en egentlig adfærdsændring. I dette henseende kan SDT suppleres af Fogg's ${ }^{2}$ Behavioral Model (FBM), der anlægger en adfærdspsykologisk vinkel på motivation. Hvor SDT indgår direkte som en del af interviewguiden, indgår FBM i den teoretiserende diskussion, hvor teorien er forsøgt appliceret i samspil med SDT. FBM tilskriver at adfærd er et produkt af tre samtidigt tilstedeværende faktorer: motivation, tilgængelighed (eng. ability) og et skub (eng. trigger) (Fogg, 2009). FBM er ikke udviklet med henblik på fysisk aktivitet eller en idrætskontekst, men kan ifølge Fogg (2009) give indsigter om adfærdsændringer inden for forskellige domæner som eksempelvis salg, uddannelse og sundhed.

En grundtanke i FBM er, at mennesket fundamentalt er dovent og at "simplicity changes behaviors" (Fogg, 2009, p. 5). Simpel adfærd kan ifølge modellen skabes ved at gøre adfærden 1) hurtig at udføre, 2) billig, 3) mindre fysisk anstrengende, 4) mindre mentalt anstrengende, 5) mere socialt accepteret og 6) mere genkendelig (Jensen, 2017).

\section{Metode}

Studiet er udformet som et casestudie og blev foretaget på et IOD seniorhold i Brabrand IF, en bydel i Aarhus beliggende i Aarhus Kommune. Et casestudie kan defineres som en empirisk unders $\varnothing$ gelse, der undersøger et fænomen i dybden og i dets kontekst (Yin, 2014). Denne forskningsstrategi giver mulighed for at foretage en dybdegående undersøgelse af seniorers motivation og barrierer. Casestudiet kan karakteriseres som et single indlejret casestudie (Yin, 2014). Der er tale om en single case frem for et multiple casestudie, fordi problemstillingen undersøges i en enkelt kontekst og fokus er på at forstå de enkelte aktørers motivation og barrierer frem for at have fokus på casens kontekst og casens globale natur, som karakteriserer et holistisk case arbejde (Yin, 2014). Casen er instrumentel i den forstand, at den bruges som illustration til at opnå en større forståelse af problematikken og sætte fokus på emnet idrætsmotivation (Creswell, 2013).

Casestudiet som metode har vist sig at være et frugtbar design til at opnå viden om seniorers motivation og barrierer for at deltage i IOD. At undersøge problemstillingen kvalitativt med semistrukturerede interviews har givet nuanceret og detaljeret viden sammenlignet med større kvantitative undersøgelser. Undersøgelsens empiri bygger udelukkende på udtalelser fra seniorer, som er aktive til IOD. En åbenlys faldgruppe ved at inddrage aktive seniorer er således en lidt svagere belysning af barrierer, mens belysningen af motivation og fastholdelse er stærkere. Derfor kan der i visse henseender have været en skævvridning, da informanterne fremhæver mange positive elementer ved IOD, hvor man kan savne flere kritiske perspektiver. I et fremtidigt forskningsperspektiv er det relevant at foretage empiriske studier blandt inaktive seniorer, som endnu ikke er en del af en idrætsforening. Dette perspektiv kan give et mere nuanceret indblik $\mathrm{i}$ og en udvidet forståelse af, hvilke barrierer seniorer har for at dyrke foreningsidræt.

\section{Feltarbejde, screening og semistrukturerede interviews}

Studiet tager udgangspunkt i den kvalitative metodologi og empirien er primært indsamlet via semistrukturerede interviews. For at kvalificere interviewundersøgelsen indledtes studiet med feltarbejde, et ekspertinterview og en screening af mulige respondenter. I feltarbejdet inddrages egen person og ved at tage del i det felt, der studeres, kan selvfølgeligheder, der ikke omtales eller diskuteres, mærkes og man kan tilegne sig viden om casen (Hastrup, 2020). Feltarbejdet er brugt aktivt i analysen, idet det har givet en forstålse af casen, af IOD og for seniorerne, der indgår i undersøgelsen.

I umiddelbar forlængelse af feltarbejdet, blev der foretaget et indledende ekspertinterview (Kvale \& Brinkmann, 2009) med en af tovholderne på IOD-holdet. Formålet med ekspertinterviewet var at kvalificere resten af undersøgelsesprocessen ved at give indblik i, hvilke tematikker og problematikker, der var relevante at undersøge nærmere og inkludere i interviewguiden.

Informanterne er valgt ud fra en strategi om at søge maksimal variation for bedst muligt at belyse problemstillingen (Launsø, Olsen, \& Rieper, 2017). Dette er gjort ved at lave en screening $\mathrm{i}$ form af en survey med undersøgende baggrundsvariable for deltagerne. Selekteringen beroede på deltagernes køn, alder, uddannelse, idrætserfaringer og fysisk aktivitetsniveau.

Dette for at sikre, at informanterne er repræsentative for casen. Der er på baggrund af screeningen udvalgt ni informanter, som har deltaget $i$ semistrukturerede interviews. I det semistrukturerede interview har samtalen et fokuseret emne og indeholder på forhånd forberedte spørgsmål, men tillader samtidigt at inddrage nye vinkler på emnet, der opstår i mødet mellem interviewer og informant (Thing \& Ottesen, 2013). Der er på forhånd udformet en interviewguide og undervejs stilles der uddybende, afklarende og opfølgende spørgsmål. Interviewpersonerne er anonymiseret og der er indhentet informeret samtykke fra alle interviewpersoner.

\section{Analysestrategi}

Analysestrategien $\mathrm{i}$ dette studie er inspireret af teoretisk læsning, som er kendetegnet ved, at den ikke omfatter brug af en bestemt analyseform, men derimod blander forskellige analysemetoder og -teknikker (Kvale \& Brinkmann, 2009). I studiet tages der udgangspunkt i en deduktiv analysestrategi, hvor der arbejdes teoristyret og interviewene læses og tolkes på baggrund af teorien (Brinkmann, 2014). Selvom analysen foregår på baggrund af en teoretisk forståelse $\mathrm{i}$ kraft af Deci og Ryans motivationsteori, har det været tilsigtet at være udforskende $i$ analysearbejdet. Derfor har analysen ligeledes haft et eksplorativt sigte, idet der har været en åbenhed over for emner og tematikker, der ikke indgår $\mathrm{i}$ SDT og disse er ligeledes inddraget $i$ analysen. Interviewene er transskriberet, kodet og analyseret, og der er anvendt et kondenseringsskema med det formål at skabe overblik over fortolkningsprocessen (Launsø et al., 2017). Slutteligt er der foretaget en tværgående analyse med henblik på at finde ligheder og forskelle i temaer, motiver, barrierer og meninger blandt informanterne (Kristiansen, 2020). 


\section{Casebeskrivelse - Idraet om dagen i Brabrand IF}

"Skal den helt ud på Brabrandstien, Poul?", råber en af kvinderne grinende, da Poul giver bolden et ordenligt slag med ketsjeren, să den ryger langt ud over baglinjen og rammer idrætssalens bagvæg, der vender ned mod Brabrandstien. Humøret er højt, der bliver grinet og smilet på banerne og snakken går lystigt hen over badmintonnettene hos de 16 fremmødte seniorer til IOD torsdag formiddag i Brabrandhallen. Stemningen er god og snakken går.

Tidligere er deltagerne kommet dryppende alene eller i små grupper til Brabrandhallen slæbende på idrætstasker, med træningsmåtte under armen og med en termokande i den ene hånd. Seniorerne møder op på trods af, at det er en tid, hvor Covid-19 påvirker det danske samfund, så der bliver afsprittet hænder og holdt god afstand. Kun et enkelt ægtepar har meldt afbud grundet Covid-19 smitterisikoen, men de fremmødte seniorer lader ikke til at bekymre sig synderligt. Opvarmningen er første punkt på dagsordenen. Deltagerne former en stor cirkel med god afstand til hinanden, en af deltagerne foreviser $ø$ velser og de andre følger med. I midten af cirklen står en ghettoblaster af æeldre dato og spiller Rasmus Seebach, YMCA og andre pophits med god, fast rytme. Efter opvarmningen fordeler deltagerne sig på floorball, badminton, pickleball ${ }^{3}$ og new age kurling ${ }^{4}$. Der er også bordtennis, men det er der ikke så mange, der er interesserede i. Holdinddelingen foregår helt naturligt. "Vil du spille med mig?" spørger én, hvorefter en anden bekræfter og inden længe er alle deltagerne fordelt på de forskellige idrætsgrene. Ved et vue ud over hallen, ses en flok seniorer, som virker idrætsvante, sunde, raske og glade.

\section{Resultater}

\section{Ekstrinsiske motiver} Sundhed

Studiet viser, at seniorerne har en række ekstrinsiske motiver. At styrke sin sundhed er et af de mest forekommende ekstrinsiske motiver og det er en udpræget opfattelse blandt informanterne, at idræt har stor indflydelse på sundhed, sygdom og smerter. Denne type motivation kan karakteriseres som identificeret motivation, der dækker over, at man handler, fordi der er et fordelagtigt udfald forbundet med den givne adfærd. Fysisk sundhed betragtes af seniorerne som "et hovedformål" (Arne, 68 år) og det anses som vigtigt "at dyrke nogle sunde interesser" (Kent, 71 år). Informanterne nævner ligeledes, at deres mentale sundhed er et motiv for at være fysisk aktiv og flere fremhæver, at de bliver gladere, făr mere energi og bedre trivsel, når de er fysisk aktive.

\section{En god alderdom}

Flere af seniorerne dyrker idræt for at holde sig i gang og dermed opnå en god alderdom. En af IODdeltagerne beskriver det således: "Min store skræk det er at blive gammel (griner) og affældig. Så kan jeg på nogen måde selv gøre noget til, at jeg far et godt otium og et godt ældreliv, så er det motivation for mig at gøre noget. Yes" (Hanne, 69 år). Deltagerne giver udtryk for, at den fysiske

${ }^{3}$ Pickleball er en blanding mellem badminton, tennis og bordtennis. Der spilles på en badmintonbane, men nettet er i tennishøjde. Bolden er en særlig pickleball plasticbold og battet er en del større end et bordtennisbat. Der kan spilles single såvel som double.

${ }^{4} \mathrm{New}$ age kurling er et spil, hvor 2-4 deltagere leverer sten fra den ene ende af banen til den anden ende af banen. Der spilles på en badmintonbane, hvor hele længden og halvdelen af bredden benyttes. For enden af banen er målet aktivitet smitter positivt af på andre aspekter af livet, idet de fortsat kan deltage i aktiviteter, opretholde deres funktionsniveau, klare dagligdagens gøremål, indgå i sociale sammenhænge og lege med børnebørnene.

\section{At følge den sociale norm}

Nogle af seniorerne har en følelse af, at man bør være fysisk aktiv og dyrke idræt. Denne overbevisning er nok udsprunget af en social norm om, at man bør dyrke motion og det øgede fokus på idrættens sundhedsfremmende potentiale. Denne type motivation kan betegnes som introjiceret motivation, fordi overbevisningen ikke er udsprunget af egne normer, men i stedet af ydre forventninger. Lis beskriver det således: "der sidder jo en lille orm og gnaver, hvis man sidder for lang tid i lænestolen" (Lis, 72 år). En af årsagerne til at handle på introjiceret motivation er at undgå dårlig samvittighed og flere af seniorerne beskriver, at de kan fă dårlig samvittighed, hvis ikke de er fysisk aktive.

\section{De tre psykologiske behov}

I de tidligere præsenterede tre psykologiske behov skelnes mellem, autonomi, kompetence og tilhørsforhold, som kan være motiver og samtidig sikre, at behov kan opfyldes. Studiet viser, at seniorerne motiveres af variation i idrætsaktiviteter, idrætserfaring og at indgå i et fællesskab. Disse motiver kan defineres som integreret motivation, idet de er relateret til de tre psykologiske behov. Samtidigt ses det, at seniorerne făr opfyldt de tre psykologiske behov gennem deltagelse i IOD.

\section{Autonomi}

Der er en generel opfattelse blandt informanterne af, at variationen i idrætsaktiviteter og muligheden for selv at vælge, hvilken idrætsaktivitet, de vil deltage i, var af afgørende betydning for, at de valgte IOD frem for et andet idrætstilbud. Seniorerne kan fra gang til gang vælge mellem en palet af idrætsgrene, alt efter hvad, de har lyst til: "Der er floorball, hvor vi fär sved på panden og pulsen højt $i$ vejret. Og så badminton ligesadan. Og så er der Pickleball, der er lidt mere roligt. Og øh skal vi slappe lidt af, så tager vi curling. (Griner) (Kent, 71 år). Mennesket er motiveret af at have medbestemmelse og indflydelse på de aktiviteter, det deltager $\mathrm{i}$, og rammerne til IOD tillader netop, at seniorerne har medindflydelse og valgfrihed.

Følelsen af autonomi påvirkes af de omgivelser, man befinder sig $i$, idet kontrollerende omgivelser underminerer følelsen af autonomi, mens omgivelser, der tillader mennesket at handle på baggrund af egne interesser og valg, øger følelsen af selvbestemmelse. Seniorerne til IOD har stor medbestemmelse med hensyn til valg af idrætsaktiviteter, holdinddeling, træningens forløb og kaffeseancen efter træningen. Rammerne omkring IOD er meget åbne, og det er op til seniorerne at udfylde dem og det betyder, at idrætstilbuddet tilpasses efter deltagerens ønsker, behov og interesser. De frie rammer til IOD formuleres således: "Der er ikke nogen, der forlanger af dig, at nu skal du bare køre bum bum bum bum, vi skal nærmest være halvprofessionelle. Det er der ikke én, der sætter krav om hernede. Det kører på vores præmisser" (Jette, 66 år). Denne oplevelse går igen hos flere af seniorerne, der understreger, at deres idrætsdyrkelse er drevet af lyst og valgfrihed frem for et ydre pres.

markeret med røde, hvide og blå cirkler. Scoringen afhænger af antallet af sten nærmest centrum af mălet og vinderen er den spiller, der har flest point ved slutningen af spillet. 


\section{Kompetence}

Der synes at være en tendens til, at seniorerne vælger idrætstilbud ud fra deres tidligere idrætserfaringer, og det virker motiverende, at det er idrætsgrene, som de har erfaringer med og selvtillid og kompetencer indenfor. Flere af informanterne fremhæver dog ogsă, at IOD betragtes som et begyndervenligt idrætstilbud, der passer til forskellige fysiske aktivitets- og færdighedsniveauer: ".. vi følte, at det var på et niveau, vi kunne klare os pa. Fordi vi har aldrig været idrætskvinder og mand, eller hvad man nu skal sige" (Emma, 71 år). Behovet for kompetence opfyldes, når ens færdigheder og erfaringer er tilstrækkelige til at mestre en given situation. Til IOD făr seniorerne succesoplevelser med idrætten, fordi deltagerne hver især kan indrette træningen således, at deres fysiske kompetencer er tilstrækkelige til at matche de udfordringer, de møder til IOD: "Der er jo nogen, der altså primært spiller curling, og det er jo fint, hvis det passer bedst til... Jamen både ens krop og ens kondition og ens formån, ikke. Det er jo, det er jo til pensionister med alle grader af bevægelsesmønstre, ikke også, og aktivitetsniveauer" (Karen, 67 år).

\section{Tilhørsforhold}

Seniorerne anser det sociale samvær som et vigtigt motiv for at starte til IOD, og flere lægger vægt på, at det at blive en del af et fælleskab havde stor indflydelse på, at de startede til IOD. Flere er blevet tiltrukket af den holdånd, der kan være i forbindelse med holdidræt, og foretrækker idræt $i$ et fællesskab frem for at være fysisk aktiv på egen hånd. Seniorerne har en oplevelse af, at alle deltagerne er i samme båd: De er alle pensionister, ingen af dem er de store idrætsudøvere, men de har en fælles interesse i idrætten og fællesskabet omkring den. Seniorerne synes, der er et godt socialt fællesskab på holdet, de trives i samvær med hinanden og der er snak på kryds og tværs mellem dem. Det indikerer, at seniorernes behov for tilhørsforhold opfyldes, idet de føler sig inkluderet i det sociale fællesskab. Næsten samtlige informanter giver udtryk for, at særligt kaffeseancen efter træningen er vigtig for at opnă en fællesskabsfølelse og for at lære hinanden at kende.

\section{Intrinsisk motivation}

Den intrinsiske motivation ser ud til at være udpræget blandt seniorerne. Det kommer blandt andet til udtryk i interviewet med Bente, da hun skal svare på, hvorfor hun går til IOD: "Det er fordi, jeg kan lide det! Det er fordi, jeg kan lide idrætten! Det er fordi, jeg godt kan lide den form for idræt" (Bente, 73 år). IOD er et idrætstilbud, hvor seniorerne har det sjovt med at dyrke idræt, de gør det, fordi de kan lide det og de nyder det. Intrinsisk motiverede handlinger udspringer ifølge SDT af egen lyst og vilje. Denne lyst og vilje kommer tydeligt til udtryk i seniorernes beskrivelser af IOD. Den intrinsiske motivation ser ud til at være knyttet til IOD, og ikke til at være fysisk aktiv i det hele taget. Seniorerne fremhæver IOD som sjovere end andre fysiske aktiviteter som eksempelvis gymnastik og løb. Seniorerne kan lide at spille bold, de kan lide at konkurrere mod hinanden på små hold og de små dueller og kampe skaber glæde, sjov og gode oplevelser. Flere fremhæver pickleball som værende en særligt sjov aktivitet, som falder i deres smag og passer til deres aktivitetsniveau.

At den intrinsiske motivation er så udbredt kan sandsynligvis forklares ved, at IOD er tilrettelagt på en måde, der tilfredsstiller deltagernes behov for autonomi, kompetence og tilhørsforhold, idet opfyldelse af de tre behov fremmer intrinsisk motivation. Opfyldelse af de tre behov er af både teoretisk og empirisk betydning for seniorernes fastholdelse i idrætten. Teoretisk set medfører opfyldelse af de tre behov, at man er mere vedholdende og tilbøjelig til at fastholde aktiviteten i længere tid. Empirisk set giver deltagerne ligeledes udtryk for dette og flere af seniorerne mener, at fællesskabet måske er den mest afgørende faktor for at fortsætte til IOD: "Det [fællesskabet] er nok altafgørende [for fortsat deltagelse $i$ IOD]. Det tror jeg. Det er meget vigtigt i hvert fald. Det er

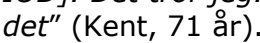

\section{Overgangen fra arbejdsliv til pensionisttilværelse}

I den eksplorative del af analysen kom det frem, at overgangen fra arbejdsliv til pensionistliv har haft en stor og betydningsfuld indflydelse på seniorernes fysiske aktivitetsniveau og har påvirket deres motivation for at dyrke idræt. Det er en udpræget opfattelse blandt seniorerne, at det at stoppe på arbejdsmarkedet har været forbundet med frigivelse af energi, overskud og tid, som nu kan give plads til mere fysisk aktivitet. Flere af seniorerne beskriver overgangen fra arbejdsliv til pensionisttilværelse som en overgangsperiode, der efterlader et tomrum med et behov for og en lyst til at fylde dagene ud med noget nyt. En af seniorerne beskriver det som at skulle "have noget andet at sætte $i$ stedet for det her øh hektiske arbejdsliv", fordi hun synes, "at så kunne dagene godt blive lange" (Hanne, 69 år). Seniorerne beskriver, at de har erstattet tomrummet efter et hektisk arbejdsliv med idræt og at idræt er med til at skabe struktur i hverdagen. Derfor foretrækker seniorerne at dyrke idræt på et fast tidspunkt, gerne om formiddagen og de værdsætter, at der er god tid, så der er plads til kaffe, hyggesnak og alt det, der er rundt om idrætten.

\section{Skubbet}

Et andet motiv, som blev klart i den eksplorative analyse er, at de fleste af seniorerne har fået et indirekte skub, før de startede til IOD. De fleste er rekrutteret via mund til mund-metoden og har fulgtes med en ven, et familiemedlem eller en bekendt, hvilket har fungeret som et skub til at komme i gang med at dyrke idræt. Det er en udbredt opfattelse blandt seniorerne, at det kan være svært at komme ud af starthullerne på̀ egen hånd, selvom der er masser af muligheder for at være idrætsaktiv som senior i Århus. De tillægger det stor betydning, at man har en at følges med, når man skal starte til et nyt idrætstilbud. En bemærkelsesværdig observation er, at der synes at være en tendens på IOD-holdet til, at det er konen, der hiver manden med til træning. En mandlig deltager beskriver det således: "Ja, det var Hanne, min kone! Hun var god til at holde mig i ørene og fă mig sparket med" (Kent, 71 år). En kvindelig deltager på IOD-holdet fortæller, hvordan en avisannonce gav hende skubbet til at starte til IOD: "Jeg så annoncen. At det var min aldersgruppe, ikke? Og jeg havde lige mistet min mand. Og så tænkte jeg: Så er det nu, du skal ud at være aktiv igen. Og så startede jeg" (Bente, 73 år).

\section{Barrierer}

Det første skridt ind i foreningen

Flere af seniorerne på IOD-holdet synes, at det kan være svært at tage det sidste skridt ud ad døren og det første skridt ind i idrætsforeningen. Hvor det fremhæves som motiverende at følges med en, kan det at skulle alene afsted omvendt være en stor barriere: "Hvis jeg af mig selv skal gå ned til et eller andet uden, at jeg har nogen at følges med. Det kan være en barriere. Der kan jeg... Der skal jeg sige til mig selv: 'Det her, det skal du' Øh. Men jeg har... Der er jeg nok lidt tryghedsnarkoman. Jeg kan godt lide, hvis der er en, jeg lige har med. Så vi er to" (Hanne, 69 
år). Seniorerne giver udtryk for, at det kan være grænseoverskridende at møde op til idræt, hvis ikke man har en at tage $\mathrm{i}$ hånden eller kender nogen på holdet på forhånd.

\section{Manglende idrætserfaring}

Seniorerne indikerer, at de har oplevet, at deres manglende erfaring med idrætten var en barriere for at indlede idrætsdeltagelse: "Jeg har jo aldrig sådan dyrket en bestemt idræt, og så synes jeg, det er svært at komme ind igen i noget, som man aldrig har dyrket, ikke?" (Emma, 71 àr). Flere giver dog udtryk for, at det var anderledes til IOD, hvilket måske skyldes, at det er begyndervenligt og at man kan dyrke forskellige idrætsaktiviteter.

\section{Helbred}

At helbred er en barriere for at dyrke idræt, kommer både til udtryk som en tidligere barriere, en aktuel og en potentiel fremtidig barriere. Flere af deltagerne beskriver, at de tidligere har haft en sygdom eller et skrantende helbred, der var medvirkende til, at de ikke dyrkede idræt. Deltagerne på IOD-holdet giver primært udtryk for, at det er det fysiske helbred, der har været og er en barriere for at dyrke idræt, men en enkelt deltager, som har været ramt af angst, depressioner og PTSD, har også oplevet det mentale helbred som en barriere. Der er bred enighed blandt deltagerne om, at det eneste de ser som en hindring for deres fremtidige deltagelse i IOD er deres helbred: "S$̊$ længe jeg kan, så vil jeg blive ved. Det er helbred. Det er udelukkende helbred, der kan stoppe det" (Arne, 68 år).

\section{Diskussion}

Når studiets resultater sammenlignes med eksisterende litteratur på området, er der overvejende overensstemmelse, men også nogle forskelle og nuanceringer.

I tidligere undersøgelser er der ligeledes fundet, at sundhed er et af seniorernes væsentligste ekstrinsiske motiver for at dyrke idræt (DIF, 2020; L. O. Ottesen et al., 2006; Sundhedsstyrelsen, 2003). Et dertil nærtbeslægtet motiv i dette studie er en god alderdom. I litteraturen fremgår dette motiv ikke direkte, men motiver som at holde sig i fysisk form (Bjerrum \& Thøgersen, 2020) og ønsket om at få overskud til resten af hverdagen (L. O. Ottesen \& Skjerk, 2006) forekommer og kan ligeledes være bidragende til en god seniortilværelse. At dyrke idræt for at følge den sociale norm er ligeledes et ekstrinsisk motiv, som er forekommende i dette studie, men som ikke er afdækket i den eksisterende litteratur. Det skyldes sandsynligvis, at de eksisterende studier er kvantitative, og det kan derfor være svært at afdække introjiceret motivation, hvis ikke der er spurgt direkte ind til emnet.

De tre psykologiske behov er i denne undersøgelse såvel som i litteraturen væsentlige motiver for seniorerne. Således er det sociale samvær et af de vigtigste motiver $\mathrm{i}$ dette såvel som i tidligere studier (Bjerrum \& Thøgersen, 2020; DIF, 2020; L. O. Ottesen et al., 2006; Pilgaard \& Rask, 2016b; Sundhedsstyrelsen, 2003; Toft, 2013). Endvidere ses det at seniorernes idrætserfaring er afgørende for deres valg af idrætstilbud, idet de er motiverede for at dyrke idrætsgrene, som de har kompetence, erfaringer og selvtillid inden for. Der er et enkelt andet studie, der finder, at det for seniorer kan være motiverende at vende tilbage til en aktivitet, de tidligere har dyrket (DIF, 2020) og det understøtter, at genkendelighed og erfaring er væsentlige motiver for at deltage $\mathrm{i}$ idræt, om end det kun belyses sparsomt $\mathrm{i}$ den eksisterende litteratur.
I litteraturen findes der dog belæg for, at seniorer motiveres af nybegyndervenlige idrætstilbud (DIF, 2020; Pilgaard \& Rask, 2016b), og at bekymring for niveauforskel er en væsentlig barriere (DIF, 2020; L. O. Ottesen et al., 2006), hvilket bekræfter at tilstrækkelige kompetence er et væsentligt motiv for seniorerne.

Et af dette studies fund er, at seniorer foretrækker at have valgfrihed mellem forskellige idrætsaktiviteter og at have indflydelse på idrætstilbuddet. Dette er motiver, som ikke forekommer i den eksisterende litteratur. Tværtimod viser et studie, at seniorerne ikke ønsker at være ansvarlige for tilrettelæggelsen af træningen (Toft, 2013). Valgfrihed og involvering eller ej, er således uklart og der er brug for mere viden for seniorer omkring dette. Intrinsisk motivation er sparsomt berørt i eksisterende studier (Bjerrum \& Thøgersen, 2020; DIF, 2020; L. O. Ottesen \& Skjerk, 2006), men er udbredt blandt deltagerne til IOD. Dette studie finder, at seniorer finder det motiverende at interagere og spille bold med andre medog modspillere, fremfor selvorganiseret aktivitet. Det er bemærkelsesværdigt, når de mest populære fysiske aktiviteter blandt seniorer over 60 år er vandreture, gymnastik og styrketræning (Sundhedsstyrelsen, 2018). Resultaterne fra dette studie peger derfor mod et potentiale for at udbrede bold- og holdspil til flere seniorer.

Dette studie peger som andre studier, på at pensionisttilværelsen ikke har arbejdslivets barrierer. Som pensionist er der tid, overskud og lyst til at dyrke idræt. Litteraturen bekræfter, at mindre arbejde og mere fritid er centrale motiver, mens arbejde og for lidt fritid er typisk oplevede barrierer for at dyrke idræe (DIF, 2020; Pilgaard, 2009; Sundhedsstyrelsen, 2003; Toft, 2013). Pensionistlivet er endvidere forbundet med nogle nye præferencer angående idrættens organisering, idet seniorerne foretrækker et fast træningstidspunkt om formiddagen og god tid, så der er plads til kaffe og snak.

Typiske barrierer blandt seniorerne i litteraturen er, at de mangler en at følges med for at opleve motivation for fysisk aktivitet (DIF, 2020; Kulturministeriet, 2009; L. O. Ottesen et al., 2006; Sundhedsstyrelsen, 2003; Toft, 2013). Det samme gør sig gældende i dette studie. Andre studier viser, at seniorer har mange praktiske barrierer. Seniorerne synes, at idræt er for dyrt (DIF, 2020; Kulturministeriet, 2009; L. O. Ottesen et al., 2006; Sundhedsstyrelsen, 2003), flere savner et passende idrætstilbud (DIF, 2020; Kulturministeriet, 2009), og gode idrætsfaciliteter (Kulturministeriet, 2009; Sundhedsstyrelsen, 2003) og seniorerne synes, at det er besværligt at komme i gang med at dyrke idræt (L. O. Ottesen et al., 2006). I dette casestudie giver seniorerne udtryk for, at opstart til IOD har været let og uproblematisk. De nævner, at der er mange senioridrætstilbud i lokalområdet, det er billigt at gå til IOD og der er ikke krav om at medbringe udstyr eller have en særlig påklædning og IOD imødekommer således en række barrierer, som er typisk forekommende blandt seniorer andetsteds.

\section{Fra motiver og barrier til handling}

FBM tilskriver, at adfærd er et produkt af tre samtidigt tilstedeværende faktorer: motivation, tilgængelighed og et skub (Fogg, 2009). 


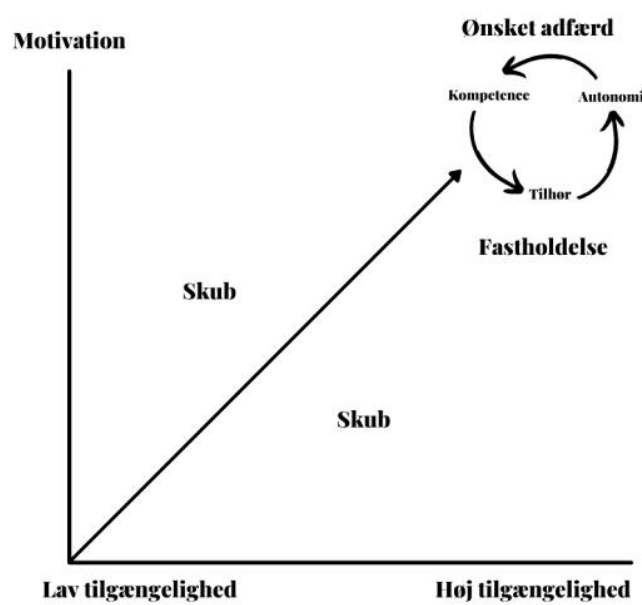

Figur 2. Revideret Fogg Behavioral Model (FBM). I øverste højre hjørne er den ønskede adfærd svarende til, at seniorerne starter til idræt. Pa modellens $y$-akse er motivation svarende til summen af in- og ekstrinsisk motivation. Modelles $x$-akse udgør tilgængelighed. Nar både motivation og tilgængelighed er høj, vil et skub igangsætte den ønskede adfærd. Det afgørende for at fastholde den ønskede adfærd er at behovet for autonomi, kompetence og tilhørsforhold opfyldes.

Når både motivation og tilgængelighed er høj, er der større sandsynlighed for, at seniorerne starter til idræt (figur 2). I analysen er der eksempler på, hvordan barrierer komplicerer deltagelse i idrætten og hvordan simplicitet og lethed gør den mere sandsynlig. For seniorerne på IODholdet gør det sig for eksempel gældende, at barrierer som manglende tid, overskud og energi var knyttet til arbejdslivet, mens de har oplevet, at deltagelse i idræt har været mere overkommeligt efter de stoppede på arbejdsmarkedet. Overgangen fra arbejdsliv til pensionisttilværelse har for mange af seniorerne betydet, at idrætten er blevet mere tilgængelig: "Det har haft stor indflydelse på aktivitetsniveauet, fordi nu havde jeg lige pludselig 24 timer til det, jeg kun havde fritiden til (...) Vi er ikke bundet af arbejdsmarkedet mere (griner)" (Poul, 75 år).

Resultaterne af studiet viser, at deltagerne på IODholdet har mange både in- og ekstrinsiske motiver og summen af disse interagerende motiver har været medvirkende til, at de er startet til IOD. Aktiveringstærsklen markerer, at når kombinationen af motivation og tilgængelighed er over aktiveringstærsklen, vil et skub på det rette tidspunkt resultere i ny adfærd og bevægelsesvaner. Et skub kan defineres som "something that tells people to perform a behavior now" (Fogg, 2009). Et succesfuldt skub er karakteriseret ved, at man opdager skubbet, associerer skubbet med den ønskede adfærd og at skubbet er til stede mens man både er motiveret og den ønskede adfærd er let tilgængelig (Fogg, 2009). Det understreger blandt andet vigtigheden af at gøre idrætstilbud synlige, så seniorerne har anledninger til at starte til idræt.

Resultaterne i studiet viste, at IOD er et idrætstilbud, som fordrer opfyldelse af deltagernes behov for autonomi, kompetence og tilhør, hvilket øger sandsynligheden for, at seniorerne fastholder idrætsdeltagelsen (Ryan \& Deci, 2000). Fællesskabet har en fastholdende effekt, fordi seniorerne føler sig forpligtede over for de andre deltagere og kan lide at indgå i fællesskabet. Medbestemmelsen virker fastholdende, fordi den er medvirkende til, at seniorerne kan vælge at dyrke de aktiviteter, de bedst kan lide samtidig med, at de selv er med til at præge idrætstilbuddet, hvilket giver ejerskab og medfører, at aktiviteterne passer til deres præferencer og behov. Medbestemmelse betyder endvidere, at de kan tilpasse idrætsaktiviteterne til deres kunnen, skavanker og skader. Det øger sandsynligheden for, at seniorerne føler sig kompetente, fordi de kan vælge passende udfordringer. Den reviderede FBM-model fungerer ved at tage højde for både motivation, tilgængelighed, barrierer og et nødvendigt skub, som kan øge sandsynligheden for, at flere seniorer bliver aktive. Modellen kan være medvirkende til at forklare, hvorfor seniorer ikke er fysisk aktive. Hvis man ønsker svar på, hvorfor seniorer ikke er fysisk aktive, kan man spørge: Mangler de motivation? Er det for svært at handle? Er der er et passende skub? (Fogg, 2009). Den reviderede FBM-model kan anvendes som et arbejdsredskab i arbejdet med at få flere seniorer til at dyrke idræt: a) man må sikre, at de er tilpas motiverede, b) har få barrierer og c) oplever idrætten som let tilgængelig. Samtidig med, at de eksponeres for anledninger (skub) til at starte til idræt. Når seniorerne er idrætsaktive, skal fokus rettes mod fastholdelsen (SDT).

\section{Praktiske implikationer}

Resultaterne fra dette studie kan omsættes til en række anbefalinger, som kan bruges i arbejdet med organisering af senioridrætstilbud og rekruttering af seniorer. De praktiske implikationer er udviklet til, hvordan man kan aktivere seniorer, der har været lidt eller meget idrætsaktive gennem livet.

\section{Organisering}

1) Senioridræt kan med fordel organiseres på en fast ugedag på et fast tidspunkt om formiddagen. 2) Sæt fokus på fællesskabet, fx ved at indføre en 'tredje halvleg' med tid til kaffe og snak. 3) Lav mellemstore hold på 12-20 personer. 4) Holdene kan med fordel være blandede dame/herre hold. 5) Det skal være muligt at deltage med sin partner. 6) Idræt kan udbydes uden træner. 7) Seniorerne skal understøttes af foreningen og idrætsorganisationen med hensyn til opstart, introduktion til nye idrætsgrene og indkøb af materialer. 8) Der kan udvælges tovholdere blandt seniorerne med ansvar for materialer, nøgler og lignende. 9) Generelt skal tilbuddet være let tilgængeligt, billigt, lokalt, begyndervenligt, have nem tilmelding og minimale krav til udstyr og påklædning.

\section{Idratten}

1) Der kan med fordel tilbydes flere idrætsgrene i samme idrætstilbud. 2) Idrætstilbuddet skal appellere bredt, så mange seniorer kan se sig selv i samme idrætstilbud. 3) Lav idrætstilbuddet nybegyndervenligt, så seniorer kan deltage, selvom de ikke har erfaring med den pågældende idræt eller idræt i det hele taget. 4) Tilrettelæg træningen ud fra den enkeltes niveau, så alle făr succesoplevelser. 5) Seniorerne værdsætter en kombinationen af boldspil, leg, konkurrence og sammenspil, hvorfor det anbefales at implementere holdidræt. 6) Giv seniorerne autonomi ved at give dem indflydelse på fx. udvikling af idrætstilbuddet, holdinddeling og valg af aktiviteter og øvelser.

\section{Rekruttering}

1) Der er et potentiale for rekruttering af seniorer $i$ overgangen mellem arbejdsliv og pensionisttilværelse. Her oplever seniorerne at have mere tid, overskud og energi og de søger efter nye aktiviteter, fællesskaber og faste holdepunkter i hverdagen. 2) Særligt mund-til-mund- 
metoden er effektiv til rekruttering af seniorer. 3) De fleste seniorer foretrækker at følges med en ven eller et familiemedlem den første gang. 4) Mange seniorer ser det som en barriere at starte til idræt alene. 5) Den reviderede FBM-model kan bruges til rekruttering af seniorer. 6) Tal ind i seniorernes motiver, imødekom barriererne og gør det let at deltage i idrætten. 7) Skab mulighed for et skub til at igangsætte handling, fx. annoncering, information, prøvetimer og tydelighed omkring idrætstilbuddet. 8) Kommunikation til seniorerne kan tage udgangspunkt $\mathrm{i}$ følgende motiver: styrke sundhed, minimere sygdom, at holde sig i gang, et godt ældreliv, fællesskab, variation i idrætsaktiviteter, genkendelighed, holdsport, boldspil og sjov. 9) Det anbefales især at imødekomme barriererne: manglende idrætserfaring og dårligt helbred.

\section{Konklusion}

Seniorerne har en række ekstrinsiske og intrinsiske motiver for at gå til IOD. De ekstrinsiske motiver er sundhed, fravær af sygdom, en god alderdom og et ønske om at følge sociale normer. Analysen viste desuden, at seniorerne har en række integrerede motiver: idrætserfaring, passende sværhedsgrad idrætsaktiviteterne, socialt samvær, variation i idrætsaktiviteter samt valgfrihed og medbestemmelse. Informanterne oplever, at det første skridt ind $\mathrm{i}$ foreningen kan være vanskeligt, at deres helbred kan udgøre en barriere og at manglende idrætserfaring kan forhindre idrætsdeltagelse. Hvor informanterne tidligere oplevede en række barrierer forbundet med arbejdslivet, har overgangen fra arbejdsliv til pensionisttilværelse givet mere tid, overskud og energi til at gå til idræt.

Det gode fællesskab på holdet opfylder behovet for tilhørsforhold, mens variationen i idrætsaktiviteter og den indlejrede valgfrihed tilfredsstiller behovet for autonomi og kompetence. Opfyldelsen af de tre behov er både teoretisk og empirisk set betydende for seniorernes fastholdelse $i$ idrætten. Endvidere manifesterer behovstilfredsstillelsen sig i, at seniorerne er overvejende intrinsisk motiverede for at dyrke fysisk aktivitet. Seniorerne kan lide at spille boldspil, dyrke idræet på hold og at konkurrere for sjov.

De praktiske implikationer på baggrund af dette studie er udviklet som hjælp til at tilrettelægge senioridrætstilbud, kommunikation til og rekruttering af seniorer. Studiet peger endvidere på, at man kan bruge den reviderede FBM-model, som en ramme for at aktivere flere seniorer i aktivitetstilbud.
Bangsbo, J., Blackwell, J., Boraxbekk, C., Caserotti, P., Dela, F., Evans, A. B., ... Vina, J. (2019). Copenhagen Consensus statement 2019: phyiscal activity and ageing. $\mathrm{Br} J$ Sports Med 2019;53, 856-858. Retrieved from https://bjsm.bmj.com/content/bjsports/53/14/856.full.p df $16 / 5-2021$

Bjerrum, H., \& Thøgersen, M. (2020). Motionstilbud i Eldre Sagen. En undersøgelse af AEldre Sagens udbud af motionsaktiviteter, deltagere og frivillige. Retrieved from Idrættens Analyseinstitut: https://idan.dk/idanundersoeger/aeldre-sagens-motionstilbud/ 16/12-2020

Brinkmann, S. (2014). Det kvalitative interview (1 ed.). København K: Hans Reitzels Forlag.

Creswell, J. W. (2013). Qualitative Inquity \& Research Design Choosing Among FIve Approaches ( 3 ed.). Los Angeles: SAGE Publications Ltd.

Deci, E. L., \& Ryan, R. M. (1985). Intrinsic Motivation and SelfDetermination in Human Behavior. New York: Plenum Press.

DIF. (2020). Bevæg dig for livets kommunale idræts- og motionsvaneundersøgelse $i$ 2020. Retrieved from https://www.bevaegdigforlivet.dk/media/8960/bevaegdig-for-livets-idraets-og-motionsvaneundersoegelser2020-tvaergaaende.pdf 16/12-2020

Eriksen, L., Davidsen, M., Jensen, H. A. R., Ryd, J. T., Strøbæk, L., White, E. D., . . Juel, K. (2016). Sygdomsbyden i Danmark. Risikofaktorer. Udarbejdet for Sundhedsstyrelsen af Statens Institut for Folkesundhed, Syddansk Universitet. . Retrieved from https://www.sst.dk/da/sygdom-og-behandling//media/Udgivelser/2016/Sygdomsbyrden-iDanmark 2016.ashx 16/5-2021

Fogg, B. J. (2009). A Behavior Model for Persuasive Design. Persuasive '09. Retrieved from https://endregion.ir/uploads/weblog/persuasive technol ogy ref/Fogg\%20Behavior\%20Model.pdf 9/9-2020

Hastrup, K. (2020). Feltarbejde. In S. Brinkmann \& L. Tanggaard (Eds.), Kvalitative metoder. En grundbog. (Vol. 3, pp. 6596). København: Hans Reitzels Forlag.

Jensen, N. H. (2017). Hjernens evolutionære design. In N. H. Jensen, A. Lieberoth, \& T. Dalsgaard (Eds.),
Adfærdsdesign (pp. 51-90). Danmark: Plurafutura publishing.

Kristiansen, S. (2020). Kvalitative analyseredskaber. In S. Brinkmann \& L. Tanggaard (Eds.), Kvalitative Metoder. En grundbog (pp. 601-621). København K: Hans Reitzels Forlag.

Kulturministeriet. (2009). Idræt for alle. Breddeidrætsudvalgets rapport - baggrund og analyse. Retrieved from København $\mathrm{K}$ : https://www.idan.dk/vidensbank/downloads/idraet-foralle/28d25647-f96e-4d74-962e-9bca0121e2b0 2/9-2020

Kvale, S., \& Brinkmann, S. (2009). InterView. Introduktion til et håndværk ( 2 ed.). København K: Hans Reitzels Forlag.

Launsø, L., Olsen, L., \& Rieper, O. (2017). Forskning om og med mennesker. Forskningstyper og forskningsmetoder $i$ samfundsforskning (7 ed.). København K: Munksgaard.

Ottesen, L. O., \& Skjerk, O. (2006). Inaktivitetsundersøgelse. Sammenfatning. Gennemført for Det Nationale Råd for Folkesundhed og Indenrigs- og Sundhedsministeriet. Retrieved

from

https://www.idan.dk/vidensbank/udgivelser/inaktivitets undersoegelse-sammenfatning/d18e716f-8472-47919cb1-981200fd785f 11/8-2020

Ottesen, L. O., Skjerk, O., \& Vang, I. K. (2006). Undersøgelse om fysisk inaktiv danskere. Kvalitativ afdækning af barrierer og motivationsfaktorer. Retrieved from København: http://cms.ku.dk//upload/application/pdf/26430dc3/Ina ktiv\%20kvalitativ.pdf 13/8-2020

Pilgaard, M. (2009). Sport og motion $i$ danskernes hverdag. Retrieved from København: https://www.idan.dk/vidensbank/udgivelser/sport-ogmotion-i-danskernes-hverdag/b9713dbd-d979-40be8391-9c7600f1e386 1/12-2020

Pilgaard, M., \& Rask, S. (2016a). Danskernes motions- og sportsvaner 2016. Idrættens analyseinstitut, 1. Retrieved from

https://www.idan.dk/vidensbank/udgivelser/danskernes -motions-og-sportsvaner-2016/03e7c32f-151c-44d2a678-a69400850057 17/8-2020

Pilgaard, M., \& Rask, S. (2016b). Danskernes motions- og sportsvaner 2016. . Retrieved from København: 
https://www.idan.dk/vidensbank/downloads/danskernes -motions-og-sportsvaner-2016/9a94e44b-4cf5-4fbeac89-a696011583d5 31/3-2020

Rask, S., \& Eske, M. (2020). Status på danskernes idrætsdeltagelse 2020, notat 1 i "Danskernes motions- og sportsvaner 2020", 29/12-2020. Idrættens analyseinstitut. Retrieved from https://idan.dk/vidensbank/downloads/status-paadanskernes-idraetsdeltagelse-2020/cb5a3970-42f44199-ba12-aca800dad3c4

Ryan, R. M., \& Deci, E. L. (2000). Self-Determination Theory and the Facilitation of Intrincis Motivation, Social Development, and Well-Being. American Psychologist, 55(1), 68-78. Retrieved from https://selfdeterminationtheory.org/SDT/documents/20 06 WilsonRogersWild JSEP.pdf 12/8-2020

Ryan, R. M., \& Deci, E. L. (2000b). Intrinsic and Extrinsic Motivations: Classic Definitions and New Directions. Contemporary Educational Psychology, 25, 54-67. Retrieved from https://www.sciencedirect.com/science/article/pii/S0361 476X99910202 14/8-2020

Ryan, R. M., Williams, G. C., Patrick, H., \& Deci, E. L. (2009). Selfdetermination theory and physical activity: the dynamics of motivation in development and wellness. Hellenic Journal of Psychology, 6, 107-124. Retrieved from https://www.researchgate. net/publication/264531505_S elf-

Determination_Theory and Physical_Activity The Dyna mics of Motivation in Development and Wellness $14 / 8-2020$

Ryom, K., Simonsen, C. B., Christiansen, S. R., Nielsen, G., 'Troelsen, J., \& Maindal, H. T.' (2020). Inaktivitet $\mathrm{i}$ Danmark, delrapport 2. Retrieved from https://pure.au.dk/portal/da/projects/studie-af-inaktivedanskere(6812c44e-e176-4dd3-900fe42065402a47).html 26/10-2020

Sheldon, K. (2012). Motivation - Viden og værktøj fra positiv psykologi (Vol. 1). København: Forlaget Mindspace.

Sundhedsstyrelsen. (2003). Befolkningens motivation og barrierer for fysisk aktivitet. Retrieved from https://www.sst.dk/da/udgivelser/2003/befolkningensmotivation-og-barrierer-for-fysisk-aktivitet 11/9-2020

Sundhedsstyrelsen. (2018). Danskernes Sundhed - Den Nationale Sundhedsprofil 2017. Retrieved from https://www.sst.dk/da/udgivelser/2018/danskernessundhed-den-nationale-sundhedsprofil-2017 2/4-2020

Sundhedsstyrelsen. (2018c). Fysisk aktivitet. Handbog om forebyggelse og behandling. Retrieved from København S: $\quad$ https://www.sst.dk/da/udgivelser/2018/fysiskaktivitet---haandbog-om-forebyggelse-og-behandling 30/10-2020

Sundhedsstyrelsen. (2019b). FEldres sundhed og trivsel ældreprofilen 2019. Retrieved from København S: https://www.sst.dk//media/Udgivelser/2019/\%C3\%86ldres-sundhed-ogtrivsel.ashx?la=da\&hash $=3835$ E7DDE20760469754D 66 649C3CACCOF47125B 22/11-2020

Thing, L. F., \& Ottesen, L. S. (2013). Metoder $i$ idrætsforskning (1 ed.). København: Munksgaard.

Toft, D. (2013). Fremtidens senioridræt - Mellem ironman og stolemotion. Retrieved from København: https://www.mariagerfjordidraetshaller.dk/images/pdf/h alanalyse/analyse/Notat_om senioridraet.pdf 27/7-2020

Vive. (2020). Tolv scenarier for fremtidens ældre. Retrieved from København

$\mathrm{K}:$ https://www.vive.dk/media/pure/14809/3837843 8/112020

Yin, R. K. (2014). Case study research. Design and methods. (5 ed.). Thousand Oaks, California: SAGE Publications, Inc. Ældresagen. (2020). Nu er hver femte dansker over 65 år. Retrieved from https://www.aeldresagen.dk/presse/videnom-aeldre/aeldre-i-tal/2020-nu-er-hver-femte-danskerover-65-aar 